\title{
Type of article: Research article "Association of ABO blood groups with craniofacial morphology among orthodontic patients of Kathmandu district"
}

Sanjay Prasad Gupta ( $\approx$ sanjayagupta2000@gmail.com )

Research article

Keywords: ABO blood groups, Craniofacial morphology, Association, Orthodontic patients

Posted Date: September 24th, 2019

DOI: https://doi.org/10.21203/rs.2.14839/v1

License: (c) (1) This work is licensed under a Creative Commons Attribution 4.0 International License.

Read Full License 


\section{Abstract}

Background: The craniofacial morphology and blood groups both are related to genetic components, hence it can be hypothesized that blood groups have an association with craniofacial morphology. Some studies showed the relationship whereas others could not find any relationship that may be due to geographic diversity of the population. The aim of this study was to find out the relationship between $\mathrm{ABO}$ blood groups and craniofacial morphology among orthodontic patients of Kathmandu district.

Materials and Methods: In this cross sectional study, a total of 385 participants (age range from 13-45 years) were selected among the orthodontic patients who came for orthodontic treatment in private orthodontic clinics. After obtaining written consent, all the patient's demographic information were recorded and lateral cephalograms were obtained from the patient's record. Blood group of all the participants was recorded.

Results: The study found that among the total of 385 participants, $162(42.07 \%)$ were male while 223 $(57.93 \%)$ were female and the mean age was $16.31 \pm 4.38$ years. Twenty cephalometric parameters depicting craniofacial morphology were digitally analyzed using lateral cephalogram. The prevalence of blood group 0 patients was highest (32.20\%) followed by blood group B (30.64\%), blood group A (29.88\%) and blood group AB (7.28\%). Statistical analysis with one way ANOVA was used for association of numerical data and blood groups that revealed nine out of twenty cephalometric parameters were statistically significant among different blood groups $(p<0.05)$. Tukey post hoc test was done to find out where the significant difference occurs among the groups.

Conclusions: The evaluation of the relationship between blood group and craniofacial morphology revealed that blood groups have association with some craniofacial parameters. This suggest, there may be some genetic influence of $A B O$ blood group on craniofacial morphology. Keywords $A B O$ blood groups, Craniofacial morphology, Association, Orthodontic patients

\section{Background}

Blood groups are inherited through genes on chromosome number 9 and $\mathrm{ABO}$ blood types do not change as a result of environmental influences during life. Malocclusion has been shown to affect oral health, increased prevalence of dental caries and can cause temporomandibular joint disorders. The etiology of malocclusions is multi-factorial and is not attributed to a single specific cause. Among various etiologies, genetics plays a significant role in causing malocclusions. The relative role of genetic and environmental factors in the etiology has been a matter of discussion and controversy in orthodontics [1].

Studies can reveal relationships between malocclusions and some genetic characteristics or accompanied diseases, that help to recognize and treat them. Relationship between the ABO blood group system and some oral diseases such as malocclusions is one of the important genetic characteristics. With the discovery of ABO blood groups and some enzyme polymorphs, it could be possible to determine 
the zygosity of twins, which are especially helpful in twin studies concerning the role of heritability of malocclusion $[1,2]$.

Landsteiner first described the existence of serologic differences between individuals and classify people into four groups depending on whether their red cells contained agglutinogen or not. The presence or absence of these antigens results in the four blood groups: $A, B, A B$, and $O[3,4]$.

Various studies showed that some diseases like dental caries [5], salivary gland tumors [6], chicken pox [7], malaria [8], oral cancer [9], hematological malignancies [10], ischemic heart disease [11], cholera [12], periodontal disease $[13,14,15,16]$ etc. were found to have significant association with blood groups.

Although genetic factors appear to govern the basic skeletal form and size, environmental factors have much influence on the bony elements $[17,18]$. Cephlaometric radiograph is used both as a research and a clinical tool for the study of malocclusion and skeletal structure [19]. A cephlaometric radiograph and cephalometric norms plays a significant role in assessing the anterioposterior jaw relation [20], class of occlusion [21], to formulate a treatment plan, and is a substantive tool in Orthodontics to aid orthodontic clinicians and research workers [22].

Limited studies have been conducted to find the relationship between oral and dental diseases and ABO blood group that showed contradictory findings that may be due to geographic diversity. This study was conducted to find out relationship of blood groups with craniofacial morphology of Nepalese orthodontic patients which was lacking and hoped that these findings will be helpful for further research.

The aim of this study was to determine the association between ABO blood groups and craniofacial morphology among orthodontic patients of Kathmandu district.

\section{Methods}

Three hundred eighty five participants (age range from 13-45 years) were selected among the orthodontic patients who came for orthodontic treatment treated by same orthodontist (author) in private orthodontics clinics of Kathmandu District. Sample size for this study was determined by using $\mathrm{n}=$ $Z^{2} p q / d^{2}$, where $Z=1.96$, value of $p$ is taken as $0.5, q=1-p=0.5$, allowable error $(d)=0.05$ and $n$ is required sample size. Based on these parameters, the required sample size was 384.16 hence, total 385 patients were selected.

Inclusion criteria of this study werepatients who came for orthodontic treatment in Orthodontics clinic, Kathmandu, Nepal with identified blood group and who gave consent to this study. Patients were excluded who had previous orthodontic treatment and had systemic disease or Craniofacial anomalies/Congenital syndrome. Also participants who were unaware of their blood group and those who were not willing to share the information were excluded from the study. 
Informed written consent was taken from patients or their parents. Blood group of the patient was noted in the data sheet from registered laboratory report or driving license provided by Government of Nepal.

Ethical approval were obtained from institutional review committee of Institute of Medicine, Tribhuvan university, Kathmandu, Nepal (Ref. no. 15 (6-11-E) 2/075/076) before conducting this study.

\section{Craniofacial morphology}

After obtaining the written consent, lateral cephalograms were obtained from the patient's record and digitally analyzed using Vistadent OC 1.1 software program (GAC International Inc, Bohemia, New York, USA) to obtained craniofacial morphology details of 20 cephalometric parameters such as SNA, SNB, ANB, Wits, Cond-A, Cond-Gn, Max-Mand, NSAr, SArGo, ArGoMe, SN-GoGn, FMA, ANS-Me, Max1-NA, Max1SN, Mand1-NB, IMPA, Mx1-Mn1, UL-E and LL-E (Fig. 1). Cephalometric measurements were performed by a single operator (author).

\section{Fig. 1 Digital measurements of craniofacial morphology on lateral cephalogram}

Data obtained were transferred to MS-excel sheet. The data were double entered and analyzed in SPSS software version 21.0. (Armonk, NY: IBM Corp.) with confidence level set at 95\% $(P<0.05)$ to test for significance. All procedures such as landmark identification, and measurements were repeated 4 weeks after the first examination by the same investigator. Eighty patients were selected randomly to find the errors associated with measurement and digitizing for intraobserver reliablility. To assess the reliability of the measurement, the intraclass correlation coefficients were performed and value lies between 0.87 and 0.95 .

To determine method-error of cephalometric measurements, Dahlberg's formula was used and value was less than 0.68 degrees for angular and $0.39 \mathrm{~mm}$ for linear variables that considered to be within acceptable limit [23].

\section{Results}

This cross sectional study found that among the total of 385 participants, 162 (42.07\%) were male while $223(57.93 \%)$ were female (Fig. 2) and the mean age was $16.31 \pm 4.38$ years.

\section{Fig. 2 Frequency of gender distribution}

Out of 385 respondents, most of them were of the age group 13-18 years i.e. $45.72 \%$, from the age group 19-25 years there were $33.25 \%$ respondents and from the age group of more than 25 years there were only $21.03 \%$. 
In the present study, the prevalence of blood group 0 patients was highest $(32.20 \%)$ followed by blood group B (30.64\%) then blood group A (29.88\%) while the prevalence of blood group AB patients was least (7.28\%). ( Fig. 2)

\section{Fig 3: Blood group distribution}

Almost $95.85 \%$ of the populations were Rhesus group positive and $4.15 \%$ were Rhesus group negative.

\section{Craniofacial morphology}

Craniofacial morphology (SNA, SNB, ANB, Wits, Cond-A, Cond-Gn, Max-Mand, NSAr, SArGo, ArGoMe, SNGoGn, FMA, ANS-Me, Max1-NA, Max1-SN, Mand1-NB, IMPA, Mx1-Mn1, UL-E and LL-E) were digitally analyzed using lateral cephalogram. Table 1 and 2 showed the results obtained by digital analysis of lateral cephalogram using Vistadent OC 1.1 software program. Statistical analysis with one way ANOVA was used for association of numerical data and blood groups that revealed nine out of twenty cephalometric parameters like Cond-A, Cond-Gn, Max-Mand, NSAr, SArGo, ArGoMe, Max1-SN, Mand1-NB and IMPA were statistically significant among different blood groups $(p<0.05)$. Tukey post hoc test was done to find out where the significant difference occured among the groups (Table 3).

Table 1. The association of skeletal parameters between blood group $A, B, A B$ and $O$.

Table 2. The association of dental and soft tissue parameters between blood group $A, B, A B$ and $O$.

Table 3. Tukey post hoc test for intergroup comparison of dento-skeletal parameter between different blood groups

\section{Discussion}

This cross sectional study provides information about craniofacial morphology among various blood groups. As the craniofacial morphology and blood groups both are related to genetic components, it can be hypothesized that blood groups have an association with craniofacial morphology. The purpose of this study was to identify such a possibility and to correlate ABO blood group and craniofacial morphology in orthodontic patients of Kathmandu district, Nepal.

Many studies revealed positive correlation of non O blood group with developing risk of ischemic heart disease, severe manifestations of atherosclerosis, and increased risk of infection with cholera [11,12,2426]. While $O$ blood group individuals have a $4 \%$ reduced risk of basal cell carcinoma, $14 \%$ reduced risk of squamous cell carcinoma and reduced risk of pancreatic cancer [27]. Along with this, increased risk of ovarian cancer in blood group B while Gastric cancer is more common in blood group A and least in group 0. 
Despite of several researches done so far in the medical field, only limited researches that relates $A B O$ blood groups with incidence of the oral diseases. The findings of previous studies were contradictory as some showed relationship while others did not. The reasons for this variation may be due to geographical diversity [28-31].

Findings of Demir et al. showed the significant association of different $A B O$ blood groups in the rates of colonization of periodontal pathogens in periodontal diseases [32]. Other report showed that oral pathologies like dermatophytosis are common in blood group A [33]. Study by Vivek et al. [34] showed blood group $\mathrm{O}$ had a greater chances for periodontitis while Gheisari et al. [35] showed blood group $B$ have a greater likelihood of association with maxillofacial deformities and least with blood group $A$.

Blood groups and Rh antigen, both are hereditary. Gene for ABO antigens is present on the 9th chromosome and Rh antigen gene is on the 1st chromosome [36].

Based on antigen production, the alleles were termed $\mathrm{A}$ (produce $\mathrm{A}$ antigen), $\mathrm{B}$ (produce $\mathrm{B}$ antigen), and $\mathrm{O}$ (no antigen production) [37]. Antigens also act as receptors for infectious agents so it has been associated with several diseases and deformities [38]. Blood group $O$ persons who lacks $A$ and $B$ genecoded glycosyltransferase express a fucosylated variant of the precursor [39].

Studies reported that blood group 'A' common among Eskimos, 'B' in Chinese and Indians, the group $\mathrm{O}$ in Americans, Canadian Indians, Czechoslovakians and Kenyans.

The distribution of $A B O$ blood group varies regionally, ethnically and from one population to another. In the present study, the $A B O$ blood group typing showed the same trend of prevalence as in the general Nepali population $(O>B>A>A B)[40,41]$. This study shows the highest frequency of blood group 0 (32.20\%), followed by B (30.64\%), A (29.88\%) and least with AB (7.28\%).

In Rhesus system, this study shows frequency of Rh-positive was $95.85 \%$, while only $4.15 \%$ was Rhnegative. These figures are similar to the other studies [42-45] While this finding is little higher than the findings of Pramanik et al.,[46], Chapagain et al.,[47] and Shrestha et al.,[40] who found only $0.8 \%, 0.14 \%$ and $2.7 \%$ of rhesus negative groups.

Statistical analysis with one way ANOVA revealed nine out of twenty cephalometric parameters like CondA, Cond-Gn, Max-Mand, NSAr, SArGo, ArGoMe, Max1-SN, Mand1-NB and IMPA were statistically significant among different blood groups $(p<0.05)$. This indicates some genetic influence on craniofacial morphology.

The results of this study is contradictory with the study of Shokor et al., [48] that there was no genetic influence of $\mathrm{ABO}$ blood group in relation to variation in craniofacial morphology so the prediction of malocclusion cannot be made in the respective blood group.

Genetic factors responsible for the basic skeletal form and size while environmental factors have much role on the bony elements $[49,50]$. Other study stated that environmental factors also played an 
important role in genetically-influenced facial types and growth patterns [51]. It has been found by several investigators that different ethnic groups have different dentofacial patterns $[52,53]$.

Long-term multicenter collaborative studies with diverse population groups with greater sample size and inclusion of healthy control are suggested to make more comprehensive assessment for definitive establishment of their association between blood group and craniofacial morphology.

\section{Conclusions}

In this study, the results obtained showed a higher fraction of blood group 0 (32.20\%) followed by B (30.64\%) then $A(29.88 \%)$ and least with blood group $A B(7.28 \%)$ among orthodontic patients. Statistical analysis with one way ANOVA revealed that blood groups have association with some craniofacial parameters. This suggests that there is some genetic influence of $A B O$ blood group on craniofacial morphology. The derived results can be used as a stepping stone in order to focus the research on correlation between the blood group antigens and development of malocclusion targeting highly susceptible individuals and developing customized treatment strategies.

\section{Abbreviations}

95\% Cl: 95\% confidence interval; ANOVA: Analysis of Variance

\section{Declarations}

\section{Acknowledgements}

I would like to thank Dr. Shristi Rauniyar for helping me during this study. In addition, I thank all the patients and their guardians for giving consent and participated in this study.

\section{Authors' contributions}

Principal author designed and performed the study as well as analysed the data and wrote the article.

\section{Funding}

No funding was obtained for this study.

\section{Availability of data and materials}

The datasets used and/or analyzed during the current study are available from the corresponding author on reasonable request. 


\section{Ethics approval and consent to participate}

Ethical approval were obtained from institutional review committee of Institute of Medicine, Tribhuvan university, Kathmandu, Nepal (Ref. no. 15 (6-11-E) 2/075/076) before conducting this study. Informed written consent was obtained from all the participants or from parents of the participants prior to participation.

\section{Consent for publication}

Not applicable

\section{Competing interests}

The author declare no competing interests.

\section{Author details}

Dr. Sanjay Prasad Gupta, Assistant Professor and Consultant Orthodontist, Orthodontics and Dentofacial Orthopedics unit, Department of Dentistry, Tribhuvan University Teaching Hospital, Institute of Medicine, Tribhuvan University, Maharajgunj, Kathmandu, Nepal, Tel: +977-9843585923, Email: sanjayagupta2000@gmail.com

\section{References}

1. Mossey PA. "The heritability of malocclusion: Part 2. The influence of genetics in malocclusion". Br J Orthod. 1999;26:195-203.

2. Nagan D. "The genetic contribution to orthodontic root resorption, A retrospective twin study- Natural inheritance". Master Thesis. University of Sydney. 1889.

3. Landsteiner K. Über "Agglutinationserscheinungen normalen menschlichen blutes". Wien Klin Wochenschr. 1901;14:1132-4.

4. Lewis M., et al. "Genetic linkage analyses of chromosome 9 loci ABO and AK1". Cytogenet Cell Genet. 1978;22:452-5.

5. Demir T. et al,. "The Effect of ABO Blood Types on Periodontal Status". Eur J Dent. 2007;1:139-43.

6. Pinkston JA., et al. "Cole P. ABO blood groups and salivary gland tumors (Alabama, United States)". Cancer Causes Control 1996;7:572-4.

7. Chakravartti MR and Chakravartti R. "ABO blood groups and chicken pox in an Indian population". Acta Genet Med Gemellol (Roma). 1977; 26:297-8.

8. Singh N., et al. "ABO blood groups among malaria cases from district Mandla, Madhya Pradesh". Indian J Malariol 1995;32:59-63. 
9. Vijay Raghavan MR., et al. "Incidence of ABO blood groups in oral cancer in South Kanara District". J Indian Dent Assoc. 1986;58:305-8.

10. Janardhana V., et al. “ABO blood groups in hematologic malignancies”. Cancer Genet Cytogenet. 1991;51:113-20.

11. Whincup PH., et al. "ABO blood group and ischaemic heart disease in British men”. BMJ 1990;300:1679-82.

12. Glass RI., et al. "Predisposition for cholera of individuals with O blood group. Possible evolutionary significance". Am J Epidemiol.1985;121:791-6.

13. Weber R. and Pastern W. "Uber die Frage der konstitutionellen Bereitschaft zur sog Alveolar-pyorrhoe”. Dtsch Mschr Zahnerlk. 1927;45:704-709.

14. Kaslick RS., et al. "Investigation of periodontosis with periodontitis: Literature survey and fi ndings based on ABO blood groups". J Periodontol 1971;42:420-7.

15. Roberts JA. “Blood groups and susceptibility to disease: A review”. Br J Prev Soc Med 1957;11:107-25.

16. Koregol AC., et al. “ABO blood groups and Rhesus factor: An exploring link to periodontal diseases”. Indian J Dent Res2010;21:364-368.

17. Lunstrom A. Nature versus nurture in dentofacial variation. Euro J Orthod. 1948; 6: 77-91.

18. Korkhaus G. Investigation into the inheritance of orthodontics malformation. Dental Record. 1930; 50: 271280.

19. Alam M.K., Basri R., Purmal K., Sikder M.A., Saifuddin M., Iida J. Cephalometric Evaluation for Bangladeshi Adult by Down's Analysis. Int Med J 2012a; 19: 258-261.

20. Alam M.K, Nowrin S.A., Shahid F., Haque S., Basri R. Cephalometric Characteristics of Bangladeshi adults with Class II Malocclusion. Int Res J Med Sci, 2014c; 2(11): 10-14.

21. Alam M.K., Basri R., Purmal K., Sikder M.A., Saifuddin M., Iida J. Cephalometric Norm Study in a Bangladeshi Population Using McNamara Analysis. Int Med J 2013e; 20: 84-86.

22. Talib M.A., Aziz N.S.A., Alam M.K., Basri R., Purmal K., Rahman S.A. Linear and Angular Cephalometric Measurement of Lip Morphology among Malaysian Malay. Int Med J. 2014; 20: 41-44.

23. Houston W.J.B. The analysis of error in orthodontic measurements. Am J Orthod. 1983; 83: 382-390.

24. Stakishaitis DV., et al. "Atherosclerosis of the coronary arteries and the blood group in the population of Lithuania”. Vrach Delo.1991:55-7.

25. Akhund IA., et al. "A study of relationship of ABO blood groups with myocardial infarction and angina pectoris". J Ayub Med Coll Abbottabad 2001;13:25-6.

26. Nydegger UE., et al. "Association of ABO histo-blood group B allele with myocardial infarction". Eur J Immunogenet 2003;30:201-6.

27. Wolpin BM., et al. "Pancreatic cancer risk and ABO blood group alleles: Results from the pancreatic cancer cohort consortium”. Cancer Res 2010;70:1015-23.

28. Al Ghamdi AS. "Association between ABO blood groups and severity of chronic periodontitis”. JKAU Med Sci. 2009;16:31-41. 
29. Koregol AC., et al. “ABO blood groups and Rhesus factor: An exploring link to periodontal diseases”. Indian J Dent Res 2010;21:364-8.

30. Pradhan AC., et al. "The relationship between periodontal disease and blood groups and secretor status". J Periodontal Res. 1971;6:294-300.

31. Blackwell CC., et al. "The Stonehouse study: Secretor status and carriage of Neisseria species”. Epidemiol Infect. 1989;102:1-10.

32. Demir T., et al. "Effects of different blood groups on the reproduction of periodontal pocket bacteria". Int Dent J. 2009;59:83-6.

33. Enweani I. "Dermatophytosis and Blood Group Classification. Oral Presentation Medical Congress, Nigeria First in Africa”.2005.

34. Vivek S., et al. "Association of $\mathrm{ABO}$ blood group and $\mathrm{Rh}$ factor with periodontal disease in a population of Virajpet, Karnataka: A cross-sectional study”. J Int Oral Health. 2013;5:30-4.

35. Gheisari R., et al. "The association between blood groups and maxillofacial deformities”. Indian J Plast Surg 2008;41:138-40.

36. Webert EK., et al. "Red cell, Platelet, and white cell antigens”. In: Wintrobe's Clinical Hematology. Greer JP, Foerster J, Lukens JN, Rodgers GM, Paraskevas F, Glader B. Eleventh edition, Philadelphia, Lippincott Williams Wilkins. 2004: 791-829.

37. Telen MJ. "Erythrocyte blood group antigens: Polymorphisms of functionally important molecules". Semin Hematol.1996;33:302-14.

38. Pai GP., et al. “Correlation between “ABO” blood group phenotypes and periodontal disease: Prevalence in south Kanara district, Karnataka state, India”. J Indian Soc Periodontol. 2012;16:519-23.

39. Campi C., et al. "Secretor status and ABH antigens expression in patients with oral lesions". Med Oral Patol Oral Cir Bucal. 2007;12:E431-4.

40. Shrestha L., et al. “ABO and Rh Blood Groups and their Ethnic Distribution in a Teaching Hospital of Kathmandu, Nepal” J Nepal Med Assoc. 2013;52:311-15.

41. Upadhyay-Dhungel K., et al. "Distribution of ABO and Rh blood groups in Nepalese medical students". Janaki Medical College Journal of Medical Sciences. 2013;1(2): 17-20.

42. Das PK., et al. "A Distribution of $\mathrm{ABO}$ and $\mathrm{Rh}-\mathrm{D}$ blood groups among blood donor in a tertiary care centre in South India”. Trop Doct. 2001;31:47-8.

43. Warghat N.E., et al. “ABO and Rh Blood Group distribution among Kunbis (Maratha) population of Amravati District, Maharashtra-India”. Asiatic J. Biotech Res. 2011;2(4): 479-483.

44. Rai V., et al. "Study of ABO and Rh (D) blood groups in Scheduled Caste of Jaunpur District". Anthropologist 2009;11 (2): 151-152.

45. Subhashini A.B. "Distribution of $\mathrm{ABO}$ and $\mathrm{Rh}(\mathrm{D})$ blood groups among Irulas, a tribal population of Pondicherry, India”. Anthropologist. 2007;9(2): 163-164.

46. Pramanik TAP. “Trend of blood group distribution among the different ethnic groups of Kathmandu Valley”. Nepal Medical College Journal 2006;8(4): 248-249.

Page 10/16 
47. Chapagain RH., et al. "Trend of blood group distribution among the Jirels of Nepal”. Journal of Nepal Medical Association. 2005;44: 121-123.

48. Shokor FF., et al. "Craniofacial morphology with genetic influence of ABO blood Group in malaysian orthodontic patients" Int J Pharm Bio Sci 2015;6(4):412- 418.

49. Kornstad P.A. and Per Gjermo H.N. "Less dental caries among secretor than among non-secretors of blood group substance”. Eur J Oral Sci 2007;84: 362-6.

50. Koregol A.C., et al. "ABO blood groups and rhesus factor: An exploring link to periodontal diseases". Indian J Dent Res 2010;21: 364-8.

51. King L., et al. "Heritability of cephalometric and occlusal variables as assessed from sibling with overt malocclusion". Am J Orthod Dentofacial Orthop. 1993;104: 121-131.

52. Alam M.K., et al. “Cephalometric Evaluation for Bangladeshi Adult by Down's Analysis”. Int Med J. 2012;19: 258-261.

53. Talib M.A., et al. "Linear and Angular Cephalometric Measurement of Lip Morphology among Malaysian Malay”. Int Med J. 2014 (20): 41-44.

\section{Tables}

Table 1. The association of skeletal parameters between blood group A, B, AB and O. 


\begin{tabular}{|c|c|c|c|c|c|c|c|c|c|}
\hline \multirow[t]{2}{*}{$\begin{array}{l}\text { Skeletal } \\
\text { parameters }\end{array}$} & \multicolumn{2}{|c|}{$\begin{array}{l}\text { Blood group } \\
\text { A }\end{array}$} & \multicolumn{2}{|c|}{$\begin{array}{l}\text { Blood group } \\
\text { B }\end{array}$} & \multicolumn{2}{|c|}{$\begin{array}{l}\text { Blood group } \\
\text { AB }\end{array}$} & \multicolumn{2}{|c|}{$\begin{array}{l}\text { Blood group } \\
\text { O }\end{array}$} & \multirow{2}{*}{$\begin{array}{l}\text { ANOVA } \\
\text { p-value }\end{array}$} \\
\hline & $\begin{array}{l}\text { Mean } \\
(\mathrm{SD})\end{array}$ & $\begin{array}{l}95 \% \text { CI } \\
\text { for Mean }\end{array}$ & $\begin{array}{l}\text { Mean } \\
\text { (SD) }\end{array}$ & $\begin{array}{l}95 \% \text { CI } \\
\text { for Mean }\end{array}$ & $\begin{array}{l}\text { Mean } \\
\text { (SD) }\end{array}$ & $\begin{array}{l}95 \% \text { CI } \\
\text { for Mean }\end{array}$ & $\begin{array}{l}\text { Mean } \\
\text { (SD) }\end{array}$ & $\begin{array}{l}95 \% \text { CI } \\
\text { for Mean }\end{array}$ & \\
\hline \multirow[t]{2}{*}{ SNA } & 84.33 & 79.16 & 81.66 & 75.41 & 83.66 & 78.49 & 85.00 & 75.06 & 0.526 \\
\hline & $(2.08)$ & 89.50 & $(2.51)$ & 87.91 & $(2.08)$ & 88.83 & $(4.00)$ & 94.93 & \\
\hline \multirow[t]{2}{*}{ SNB } & 80.53 & 77.46 & 79.96 & 77.66 & 77.96 & 75.82 & 81.20 & 74.74 & 0.486 \\
\hline & $(2.92)$ & 83.60 & (2.19) & 82.26 & $(2.04)$ & 80.10 & (6.15) & 87.65 & \\
\hline \multirow[t]{2}{*}{ ANB } & 3.80 & 1.66 & 1.70 & 0.23 & 5.7 & 5.04 & 3.80 & 1.81 & 0.372 \\
\hline & $(2.77)$ & 5.93 & (1.91) & 3.16 & $(0.85)$ & 6.35 & $(2.58)$ & 5.78 & \\
\hline \multirow[t]{2}{*}{ Wits } & -0.33 & -2.58 & -1.33 & -2.58 & -0.66 & -1.79 & -1.00 & -1.58 & 0.816 \\
\hline & $(3.55)$ & 1.92 & (1.96) & -0.08 & (1.77) & 0.46 & $(2.95)$ & -0.77 & \\
\hline \multirow[t]{2}{*}{ Cond-A } & 83.00 & 78.39 & 76.66 & 75.16 & 75.66 & 72.65 & 78.00 & 75.95 & 0.003* \\
\hline & $(8.32)$ & 87.60 & $(2.71)$ & 78.17 & (5.43) & 78.67 & (3.68) & 80.04 & \\
\hline \multirow[t]{2}{*}{ Cond-Gn } & 107.33 & 104.16 & 103.00 & 101.08 & 98.66 & 96.78 & 102.55 & 101.19 & $0.000 *$ \\
\hline & $(6.36)$ & 110.91 & (3.85) & 104.91 & (3.78) & 100.55 & $(2.95)$ & 104.13 & \\
\hline \multirow[t]{2}{*}{ Max-Mand } & 24.00 & 22.33 & 26.33 & 23.47 & 23.00 & 21.85 & 27.33 & 25.57 & $0.05^{*}$ \\
\hline & (3.64) & 25.66 & (6.27) & 29.19 & $(2.50)$ & 24.14 & (3.86) & 29.09 & \\
\hline \multirow[t]{2}{*}{ NSAr } & 123.33 & 121.52 & 124.66 & 123.07 & 121.66 & 120.24 & 120.00 & 118.73 & $0.000 *$ \\
\hline & $(4.28)$ & 125.14 & (3.76) & 126.25 & (3.37) & 123.09 & (3.00) & 121.26 & \\
\hline \multirow[t]{2}{*}{ SArGo } & 142.66 & 139.33 & 145.00 & 143.35 & 150.66 & 151.99 & 146.66 & 146.47 & 0.000* \\
\hline & $(8.41)$ & 145.99 & $(4.16)$ & 146.64 & (3.36) & 147.00 & $(0.48)$ & 146.85 & \\
\hline \multirow[t]{2}{*}{ ArGoMe } & 123.00 & 119.22 & 118.00 & 116.06 & 114.33 & 113.97 & 121.33 & 120.61 & $0.000 *$ \\
\hline & $(10.10)$ & 126.77 & (5.18) & 119.93 & $(0.958)$ & 114.69 & (1.91) & 122.04 & \\
\hline \multirow[t]{2}{*}{ SN-GoGn } & 30.83 & 27.48 & 29.70 & 27.22 & 29.33 & 28.46 & 31.66 & 30.92 & 0.388 \\
\hline & $(9.43)$ & 34.17 & (6.96) & 32.17 & $(2.46)$ & 30.20 & $(2.08)$ & 32.40 & \\
\hline \multirow[t]{2}{*}{ FMA } & 23.33 & 21.30 & 22.66 & 20.86 & 21.33 & 19.89 & 23.33 & 21.42 & 0.342 \\
\hline & (5.99) & 25.36 & (5.32) & 24.46 & $(4.24)$ & 22.77 & (5.63) & 25.24 & \\
\hline \multirow[t]{2}{*}{ ANS-Me } & 61.00 & 60.19 & 59.00 & 56.87 & 58.66 & 56.32 & 60.33 & 58.71 & 0.218 \\
\hline & $(2.48)$ & 61.80 & $(6.56)$ & 61.12 & $(7.22)$ & 61.00 & $(4.98)$ & 61.94 & \\
\hline
\end{tabular}

Table 2. The association of dental and soft tissue parameters between blood group A, B, AB and O. 


\begin{tabular}{|c|c|c|c|c|c|c|c|c|c|}
\hline \multirow[t]{2}{*}{$\begin{array}{l}\text { Dental and soft } \\
\text { tissue parameters }\end{array}$} & \multicolumn{2}{|c|}{$\begin{array}{l}\text { Blood group } \\
\text { A }\end{array}$} & \multicolumn{2}{|c|}{$\begin{array}{l}\text { Blood group } \\
\text { B }\end{array}$} & \multicolumn{2}{|c|}{$\begin{array}{l}\text { Blood group } \\
\text { AB }\end{array}$} & \multicolumn{2}{|c|}{$\begin{array}{l}\text { Blood group } \\
\text { O }\end{array}$} & \multirow{2}{*}{$\begin{array}{l}\text { ANOVA } \\
\text { p-value }\end{array}$} \\
\hline & $\begin{array}{l}\text { Mean } \\
\text { (SD) }\end{array}$ & $\begin{array}{l}95 \% \text { CI } \\
\text { for Mean }\end{array}$ & $\begin{array}{l}\text { Mean } \\
\text { (SD) }\end{array}$ & $\begin{array}{l}95 \% \text { CI } \\
\text { for Mean }\end{array}$ & $\begin{array}{l}\text { Mean } \\
(\mathrm{SD})\end{array}$ & $\begin{array}{l}\text { 95\% CI } \\
\text { for } \\
\text { Mean }\end{array}$ & $\begin{array}{l}\text { Mean } \\
\text { (SD) }\end{array}$ & $\begin{array}{l}\text { 95\% CI } \\
\text { for } \\
\text { Mean }\end{array}$ & \\
\hline Max1-NA & $\begin{array}{l}23.40 \\
(2.84)\end{array}$ & $\begin{array}{l}22.51 \\
24.28\end{array}$ & $\begin{array}{l}23.53 \\
(6.02)\end{array}$ & $\begin{array}{l}21.65 \\
25.41\end{array}$ & $\begin{array}{l}22.93 \\
(3.39)\end{array}$ & $\begin{array}{l}21.87 \\
23.99\end{array}$ & $\begin{array}{l}24.56 \\
(1.58)\end{array}$ & $\begin{array}{l}24.07 \\
25.05\end{array}$ & 0.256 \\
\hline Max1-SN & $\begin{array}{l}109.00 \\
(5.02)\end{array}$ & $\begin{array}{l}107.49 \\
110.50\end{array}$ & $\begin{array}{l}107.33 \\
(4.54)\end{array}$ & $\begin{array}{l}105.96 \\
108.69\end{array}$ & $\begin{array}{l}109.33 \\
(6.67)\end{array}$ & $\begin{array}{l}107.32 \\
111.33\end{array}$ & $\begin{array}{l}111.00 \\
(2.47)\end{array}$ & $\begin{array}{l}110.25 \\
111.74\end{array}$ & $0.007 *$ \\
\hline Mand1-NB & $\begin{array}{l}26.76 \\
(4.08)\end{array}$ & $\begin{array}{l}25.58 \\
27.95\end{array}$ & $\begin{array}{l}26.06 \\
(1.65)\end{array}$ & $\begin{array}{l}25.58 \\
26.54\end{array}$ & $\begin{array}{l}25.00 \\
(2.18)\end{array}$ & $\begin{array}{l}24.36 \\
25.63\end{array}$ & $\begin{array}{l}27.70 \\
(7.42)\end{array}$ & $\begin{array}{l}25.54 \\
29.85\end{array}$ & $0.027^{*}$ \\
\hline IMPA & $\begin{array}{l}87.33 \\
(4.06)\end{array}$ & $\begin{array}{l}86.18 \\
88.47\end{array}$ & $\begin{array}{l}88.00 \\
(2.97)\end{array}$ & $\begin{array}{l}85.87 \\
90.12\end{array}$ & $\begin{array}{l}88.00 \\
(2.97)\end{array}$ & $\begin{array}{l}87.16 \\
88.83\end{array}$ & $\begin{array}{l}90.33 \\
(5.61)\end{array}$ & $\begin{array}{l}88.75 \\
91.91\end{array}$ & $0.028 *$ \\
\hline Mx1-Mn1 & $\begin{array}{l}125.30 \\
(5.01)\end{array}$ & $\begin{array}{l}123.93 \\
126.66\end{array}$ & $\begin{array}{l}125.80 \\
(2.72)\end{array}$ & $\begin{array}{l}125.05 \\
126.54\end{array}$ & $\begin{array}{l}125.70 \\
(1.92)\end{array}$ & $\begin{array}{l}125.17 \\
126.22\end{array}$ & $\begin{array}{l}125.36 \\
(2.93)\end{array}$ & $\begin{array}{l}124.56 \\
126.16\end{array}$ & 0.833 \\
\hline UL-E & $\begin{array}{l}-1.00 \\
(1.64)\end{array}$ & $\begin{array}{l}-1.43 \\
-0.56\end{array}$ & $\begin{array}{l}-0.66 \\
(2.37)\end{array}$ & $\begin{array}{l}-1.29 \\
-0.03\end{array}$ & $\begin{array}{l}-1.00 \\
(0.82)\end{array}$ & $\begin{array}{l}-1.21 \\
-0.78\end{array}$ & $\begin{array}{l}-1.00 \\
(2.17)\end{array}$ & $\begin{array}{l}-1.57 \\
-0.42\end{array}$ & 0.711 \\
\hline $\begin{array}{l}\text { LL-E } \\
* \mathrm{p}<0.05 \text { (Statistic }\end{array}$ & $\begin{array}{l}-0.33 \\
(1.71) \\
y \text { signif }\end{array}$ & $\begin{array}{l}-0.77 \\
0.10 \\
\text { nt) }\end{array}$ & $\begin{array}{l}-0.33 \\
(2.37)\end{array}$ & $\begin{array}{l}-0.94 \\
0.28\end{array}$ & $\begin{array}{l}-0.33 \\
(0.95)\end{array}$ & $\begin{array}{l}-0.57 \\
-0.08\end{array}$ & $\begin{array}{l}0.00 \\
(-0.25)\end{array}$ & $\begin{array}{l}-0.36 \\
0.36\end{array}$ & 0.630 \\
\hline
\end{tabular}

Table 3. Tukey post hoc test for intergroup comparison of dento-skeletal parameter between different blood groups

\begin{tabular}{|lllll|}
\hline Parameter & Between groups & Mean Difference & Std. Error & Sig. \\
\hline Cond-A & Blood group A- Blood group B & 6.33 & 1.99 & $0.013^{*}$ \\
& Blood group A- Blood group AB & 7.33 & 1.99 & $0.003^{*}$ \\
Cond-Gn & Blood group A- Blood group B & 4.33 & 1.47 & $0.023^{*}$ \\
& Blood group A- Blood group AB & 8.66 & 1.47 & $0.000^{*}$ \\
& Blood group A- Blood group O & 4.66 & 1.47 & $0.012^{*}$ \\
& Blood group B- Blood group AB & 4.33 & 1.47 & $0.023^{*}$ \\
Max-Mand & Blood group O- Blood group AB & 4.00 & 1.47 & $0.041^{*}$ \\
NSAr & Blood group O- Blood group AB & 4.33 & 1.32 & $0.009^{*}$ \\
& Blood group A- Blood group O & 3.33 & 1.04 & $0.011^{*}$ \\
SArGo & Blood group B- Blood group AB & 3.00 & 1.04 & $0.027^{*}$ \\
& Blood group B- Blood group O & 4.66 & 1.04 & $0.000^{*}$ \\
& Blood group A- Blood group AB & -8.00 & 1.35 & $0.000^{*}$ \\
& Blood group A- Blood group O & -4.00 & 1.35 & $0.021^{*}$ \\
ArGoMe & Blood group B- Blood group AB & -5.66 & 1.35 & $0.000^{*}$ \\
& Blood group O- Blood group AB & -4.00 & 1.35 & $0.021^{*}$ \\
& Blood group A- Blood group B & 5.00 & 1.49 & $0.006^{*}$ \\
& Blood group A- Blood group AB & 8.66 & 1.49 & $0.000^{*}$ \\
Max1-SN & Blood group O- Blood group AB & 7.00 & 1.49 & $0.000^{*}$ \\
Mand1-NB & Blood group O- Blood group B & 3.66 & & \\
IMPA & Blood group O- Blood group AB & 2.70 & 1.03 & $0.003^{*}$ \\
*p<0.05 (Statistically significant) & -3.00 & 0.90 & $0.018^{*}$ \\
\hline
\end{tabular}


Figures

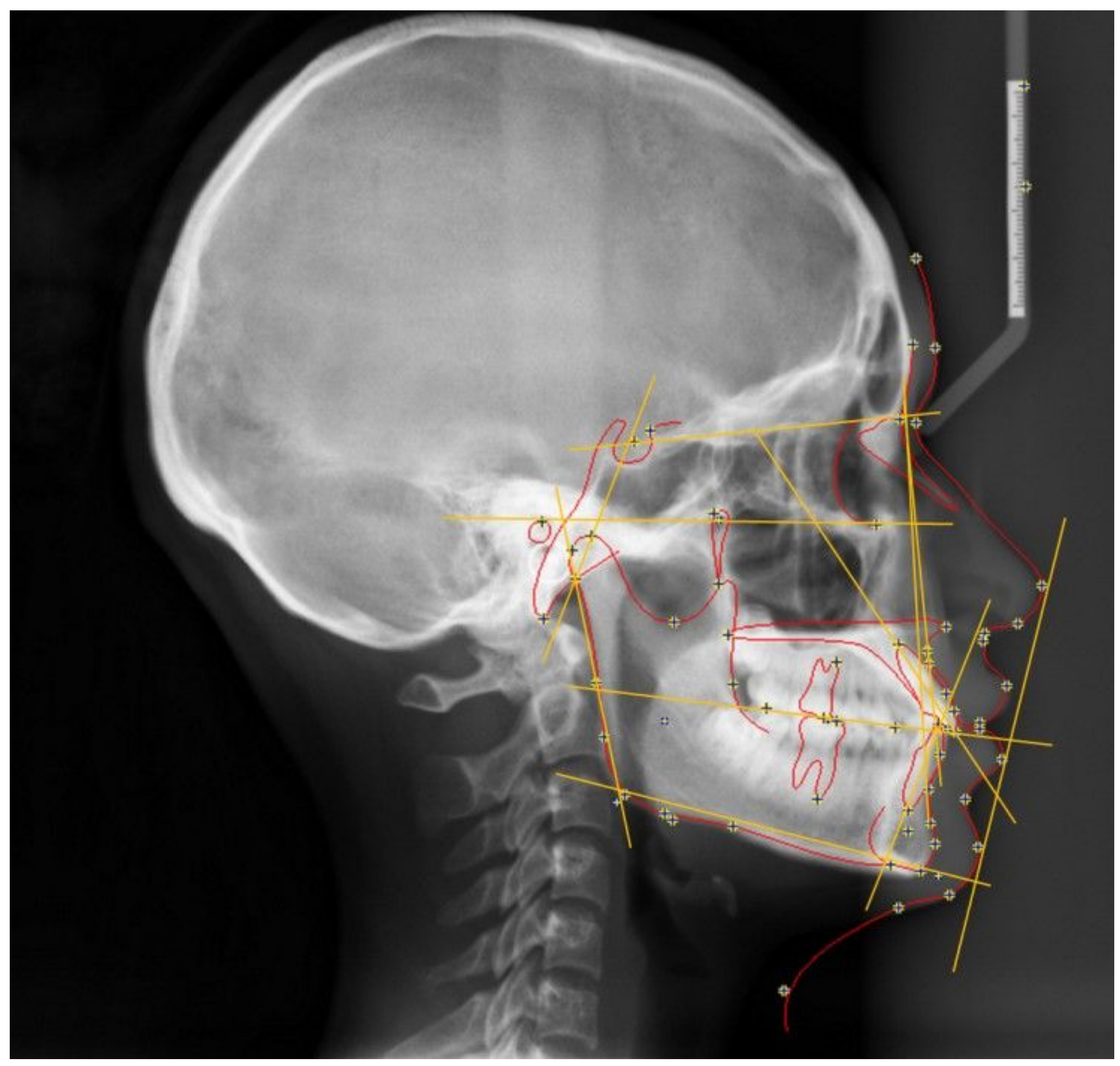

\section{Figure 1}

Digital measurements of craniofacial morphology on lateral cephalogram 


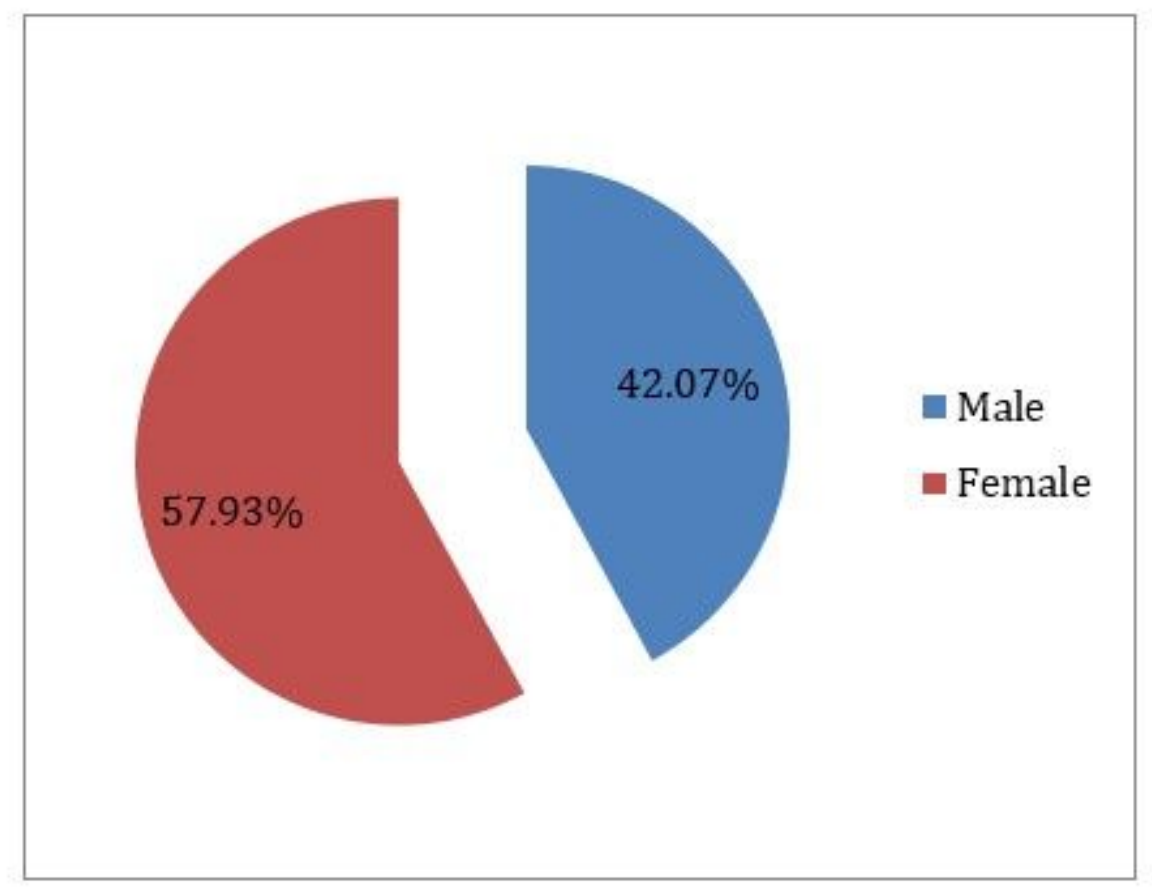

Figure 2

Frequency of gender distribution

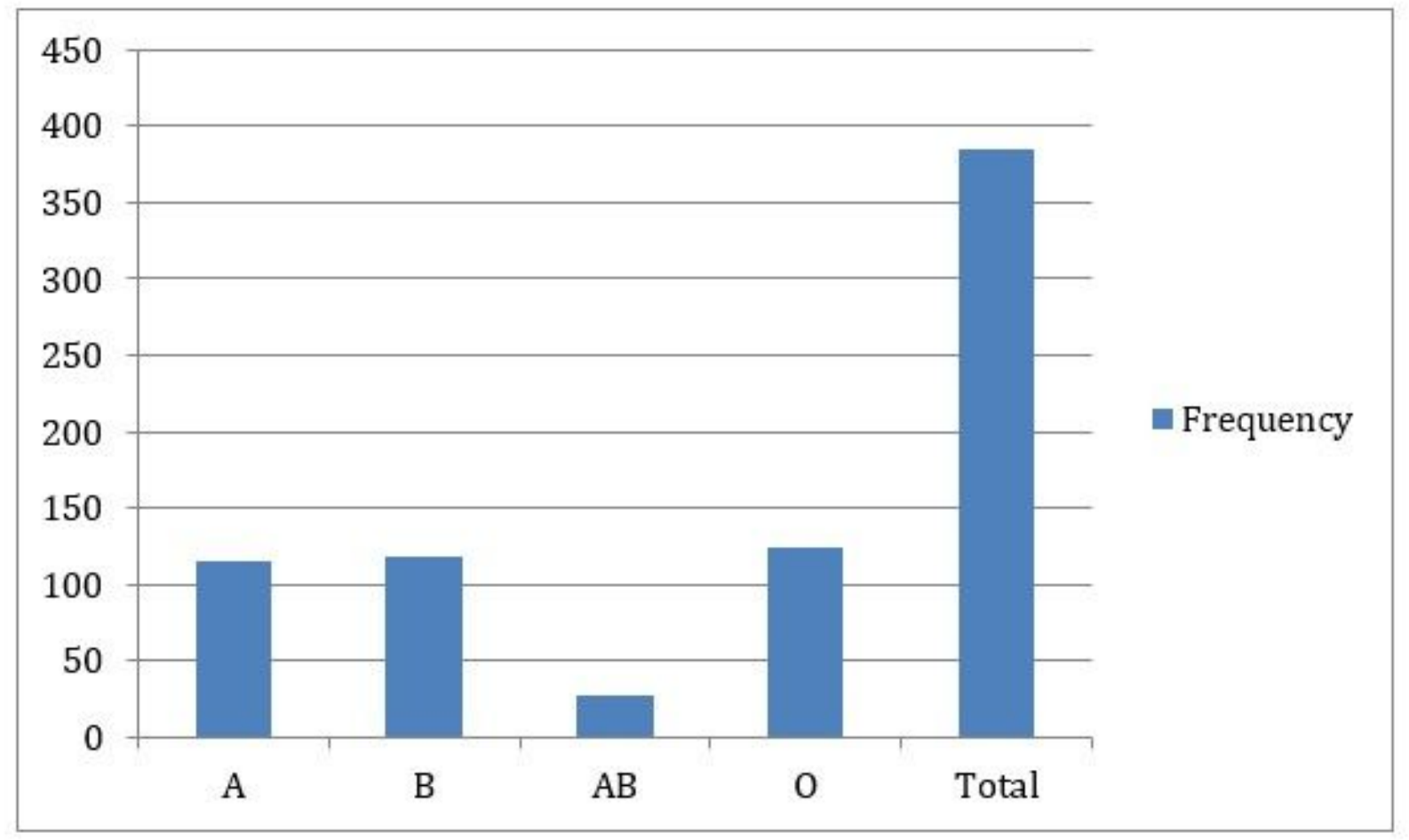

Fig. 3 Blood group distribution

Figure 3 
Blood group distribution

Page 16/16 